Acta vet. scand. $1978,19,18-29$.

From the Department of Animal Hygiene and the Department of Clinical Radiology, College of Veterinary Medicine, Swedish University of Agricultural Sciences, Uppsala, Sweden, and the Laboratory for Comparative Orthopaedics, Hospital for Special Surgery, affiliated with the New York Hospital - Cornell University Medical College, New York, USA.

\title{
BONE MINERAL CHANGES IN GROWING, PREGNANT AND LACTATING CATTLE*
}

\author{
By \\ Roland Zetterholm
}

\begin{abstract}
ZETTERHOLM, R.: Bone mineral changes in growing, pregnant and lactating cattle. Acta vet. scand. 1978, 19, 18-29. - Bone mineral content (BMC) was determined in one or two coccygeal vertebrae by dichromatic photon absorptiometry in two sets of cattle: A. This set consisted of six fattening bulls. Their increases of BMC and weights were closely correlated. However, BMC increased slightly more than weight. B. There were 28 cows in this set. BMC was measured during lactation and pregnancy. It was found that BMC increased during the dry period and decreased during early lactation. There were great individual variations in BMC, and the skeletal turnover seemed to be great.
\end{abstract}

absorptiometry; bonemineral measurement; calcium metabolism; cattle; gammaraysorce; phosphorus.

A technique with good precision (methodological error $1.5 \%$ ) for direct measurement of bone mineral content (BMC) in cattle was recently described (Zetterholm \& Dalén 1978).

The aim of the present investigation in which the new technique was applied was twofold:

- To correlate growth rate (weight increase) and changes in BMC in fattening bulls.

- To follow changes in BMC in dairy cows during pregnancy and lactation.

* This investigation was supported by The John M. Olin Foundation, the Swedish Medical Research Council, the Swedish Council for Forestry and Agricultural Research, and the Knut and Alice Wallenberg Foundation. 


\section{MATERIAL}

The material consisted of two sets of animals. The first (A) comprised six fattening bulls of the Swedish Red and White Breed (SRB), kept and fed to be slaughtered at an age of about 13 months. The second set (B) consisted of 28 dairy cows of which most went through a period of pregnancy and lactation during the time of study. With the exception of two animals, which were of the Swedish Friesian Breed (SLB), all were of the SRB breed.

A. The six fattening bulls were of about five months of age at the start of the investigation. During the entire study, the animals were fed about $0.5 \mathrm{~kg}$ of hay/day and had free access to concentrated fodder. This concentrate consisted of $42 \%$ barley, $40 \%$ oats, $10 \%$ dry beet pulp and $8 \%$ soy bean meal; $1.3 \mathrm{~kg}$ chalk and $0.3 \mathrm{~kg}$ salt with iodine was added to $100 \mathrm{~kg}$ of concentrate. The bulls, which were weighed every two weeks, were kept at the Research Station Götala, Skara, Sweden.

B. There were 14 pairs of identical twins in this set. They belonged to a herd of about 50 dairy cows kept at the Experimental Division, Viad, Grödinge, Sweden, of the Department of Animal Breeding of the Agricultural College. The period of investigation extended over one year, starting in April. The identical twins were used as calf mothers in a progeny testing of bulls. Twenty-one of the 28 cows delivered a calf during the period of the present investigation. At the start of this investigation, the mean age of the cows was four years and seven months. The range was two years and nine months - eight years and one month (Table 1).

The daily amount of milk produced by each cow was measured by weighing five days a week, and determination of the fat content was made once a week on a composite sample from each cow. The mean milk yield of the herd for the period October through September of the year of investigation was about $4,500 \mathrm{~kg}$ and $170 \mathrm{~kg}$ of fat.

Table 1. Age at the start of the investigation.

\begin{tabular}{lrrrrrrrrrrrrrr}
\hline Twins Nos. & 1 & 2 & 3 & 4 & 5 & 6 & 7 & 8 & 9 & 10 & 11 & 12 & 13 & 14 \\
\hline Years & 8 & 7 & 6 & 6 & 4 & 4 & 3 & 3 & 3 & 3 & 3 & 3 & 2 & 3 \\
Months & 1 & 5 & 8 & 5 & 11 & 3 & 11 & 8 & 6 & 6 & 0 & 0 & 9 & 3 \\
\hline
\end{tabular}


The animals were weighed every two weeks, and they were individually fed according to their weight and milk yield. The feeding regimen was the same for all animals. Four $\mathrm{kg}$ of homeproduced hay was given to a cow weighing $450 \mathrm{~kg}$. For each 20 $\mathrm{kg}$ difference in weight, $0.2 \mathrm{~kg}$ hay was added respectively subtracted from the daily ration of $4 \mathrm{~kg}$. Lactating cows were given $12 \mathrm{~kg}$ of home produced ensilage/day regardless of their weight. Likewise, the cows in the dry period were given $6 \mathrm{~kg}$ ensilage regardless of their own weight. In addition to hay and ensilage the animals were given concentrated fodder of two different kinds. One contained $10 \%$ digestible crude protein (I), the other $17 \%$ (II). The energy content of both kinds of the concentrated fodder was 11.3 megajoule $/ \mathrm{kg}$ ( 2.70 megacal./kg), and the amount of the concentrate given was determined by the calculated protein requirement of each cow. The size of the milk yield was the determining factor.

The Ca content was the same for both concentrates $(1.2 \%)$, but the $\mathrm{P}$ content differed (I $0.8 \%$, II $0.9 \%$ ). Samples of the fodder were taken continuously, and analysis of composite samples was made at least every second month. The amount of dry matter, crude protein, energy, Ca and $P$ was determined (Fig. 1). If the animals did not consume all the fodder which was given to them, the remains were carefully weighed every day.

Ten of the animals were kept on pasture during the period May through September, while the other animals were kept indoors. One of the animals on pasture was in her dry period and her BMC was therefore not measured during this time. The animals were tied by cross chains and no feeding barrier was used.

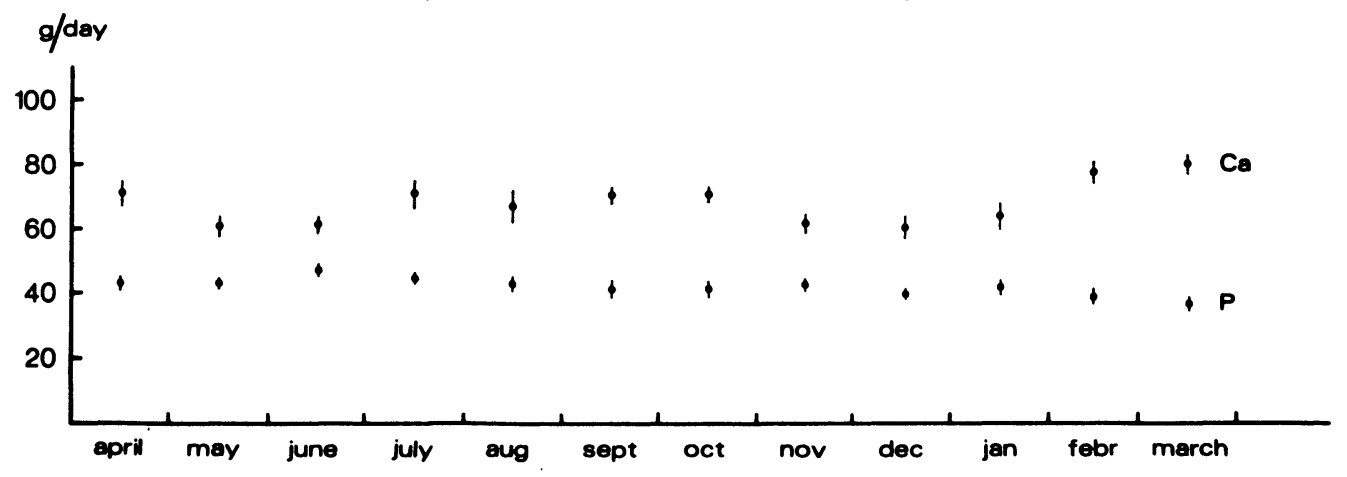

Figure 1. Ca and $P$ (mean \pm 1 s.e.m.) given for maintenance and foetal development. In addition $2.6 \mathrm{~g} \mathrm{Ca}$ and $1.8 \mathrm{~g} \mathrm{P}$ were given/kg produced milk. 
Blood samples were taken six times during the investigation. Serum $\mathrm{Ca}$ and $\mathrm{Mg}$ were determined with an atomic absorption spectrophotometer. Inorg. $P$ was determined as modum Fiske \& Subarrow, and alkaline phosphatase with Boehringer's reagent.

\section{METHOD}

A. Bone mineral content in two coccygeal vertebrae at the middle of the tail was measured at approximately monthly intervals. The first measurement was made when the weight of the animals first exceeded $140 \mathrm{~kg}$. The value of the first measurement was used as the zero point. Subsequent values were expressed as percentage increase or decrease of this value. The weight of each animal was expressed as percentage deviation from the weight obtained at the first weighing after the first measurement. BMC and weight were plotted. The increases of body weight and BMC were compared by t-test. The correlation coefficient between increase of weight and BMC was determined.

B. Bone mineral content in one coccygeal vertebra (either No. V, VI or VII) was measured approximately at monthly intervals during a whole year in all animals except two, in which only eight respectively 10 measurements were made. The value obtained at the first measurement was used as the zero point. The subsequent values were expressed as percentage deviation from this value and plotted. The mean BMC for all the 28 animals was calculated and plotted on a curve using the percentage deviation of each mean value from previous mean value as points of reference. In this way, two curves were obtained. One gave the changes in mean values during the year of investigation. The other curve was made in such a way that the difference in mean BMC changes during lactation was shown (as zero point was chosen the value of the measurement closest to calving day).

\section{RESULTS}

A. As is seen in Figs. 2 and 3, the increase in BMC was significantly more marked than the increase in body weight in all six animals $(P<0.001)$. The correlation coefficient between increase of weight and $\mathrm{BMC}$ for each animal was $0.99,0.99,0.99$, $0.98,0.97,0.93$ respectively.

B. There was considerable individual variation in BMC in the animals of this set (Figs. 4-6). The mean BMC showed a peak 

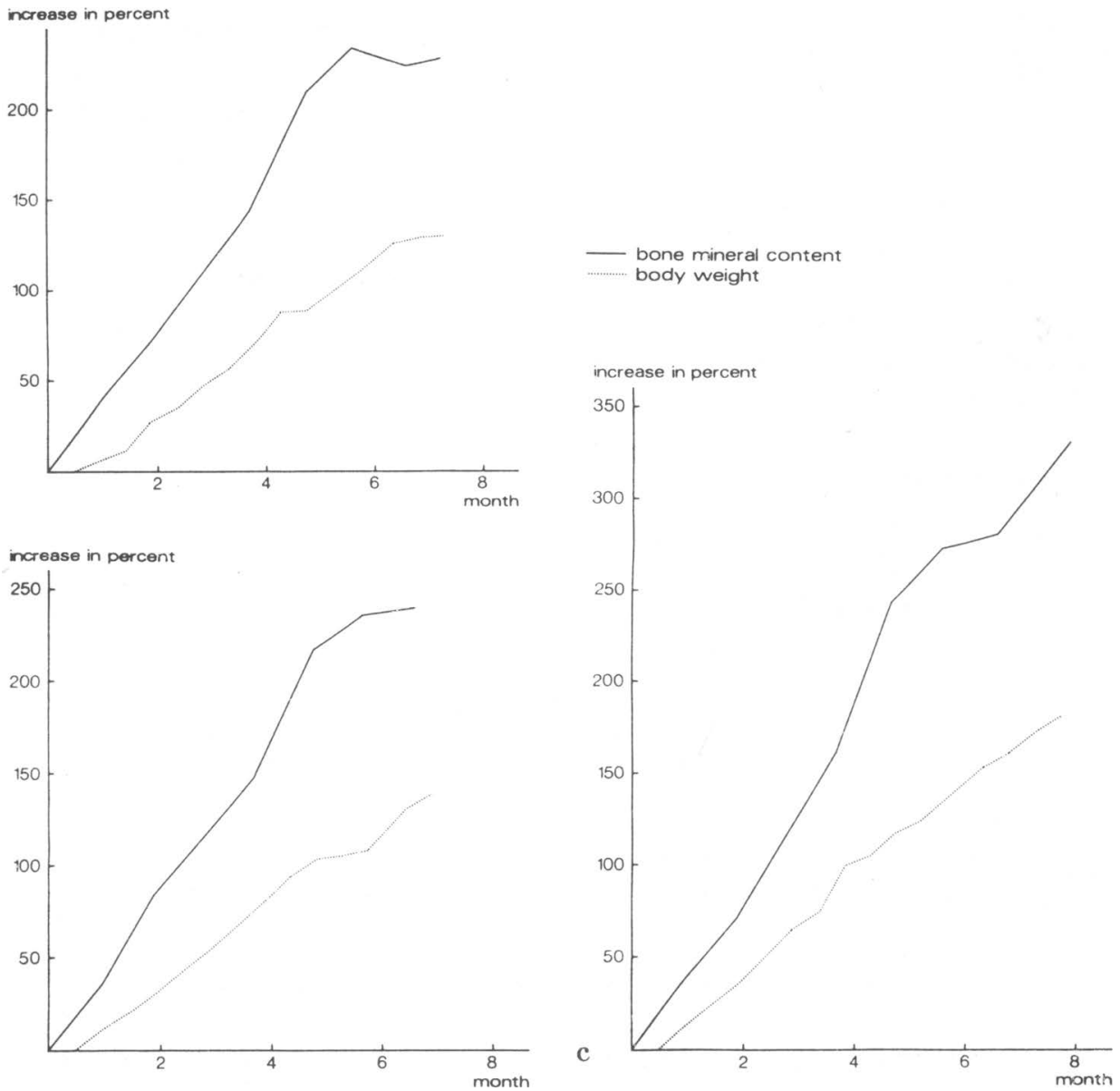

Figure 2 a-c. Increase in weight and BMC expressed in percentage of value obtained at start of investigation.

at the months of October and November (Fig. 7). However, the mean BMC for the cows which calved during the second half of the year of investigation showed a similar pattern (nine of the 11 cows calved from mid-December to mid-January). The mean BMC for the animals which for some time during the investigation were on pasture also showed a peak value at the same time. Before and after this period their mean BMC seemed to differ slightly from that of the entire $B$ set.

When the BMC value obtained at the determination closest to the calving was used as the zero point, it was seen that the 

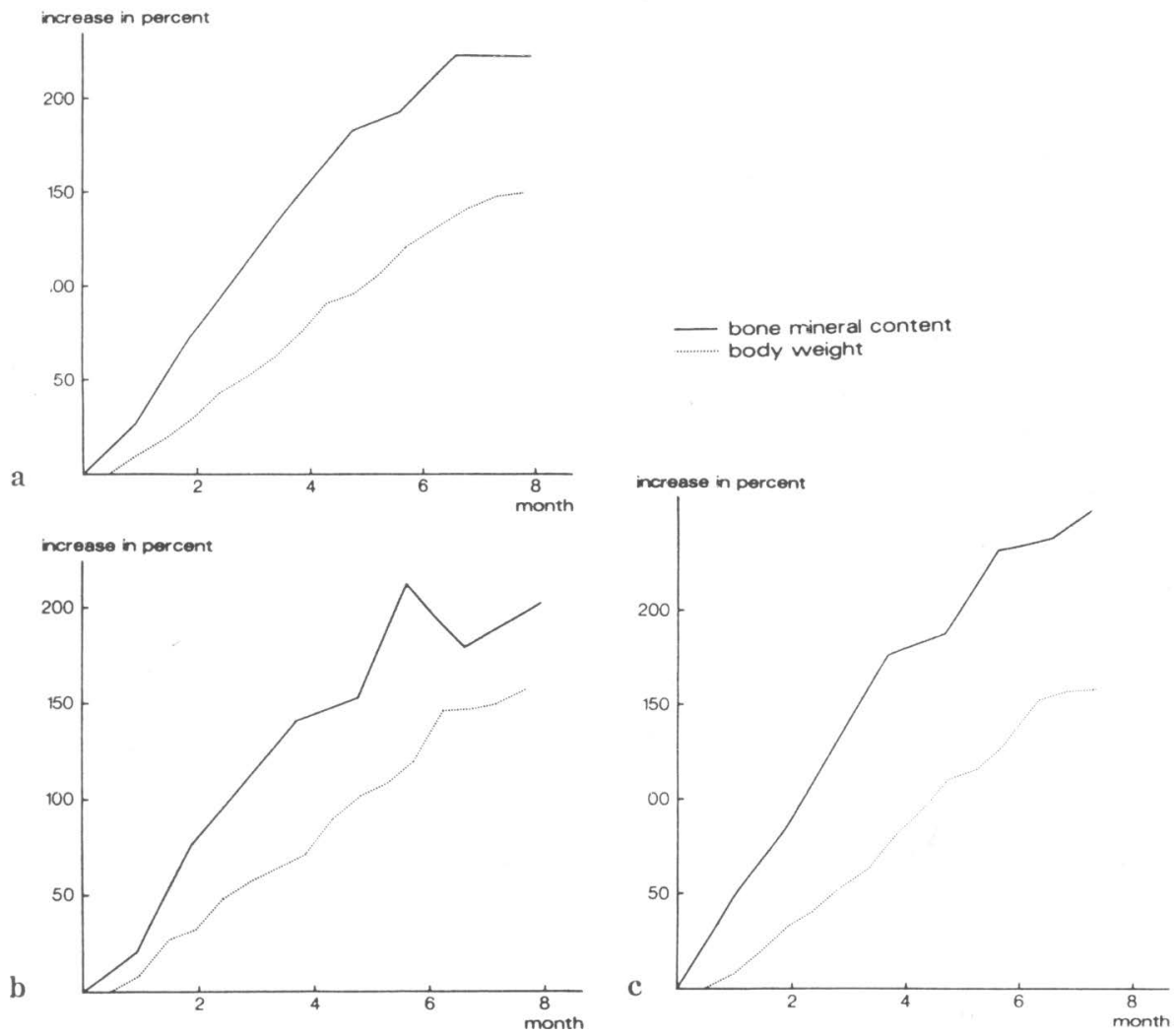

F i gure 3 a-c. Increase in weight and BMC expressed in percentage of value obtained at start of investigation.

mean BMC only fell below this value during early lactation. At this period the range was, however, the greatest. The mean BMC seemed to increase somewhat at the end of lactation and during the dry period (Fig. 8).

The values obtained by blood analyses were within normal range with the exception of inorg. $P$, which was low at the first examination (Table 2).

T a b l e 2. Blood analyses, mean and s.

\begin{tabular}{|c|c|c|c|c|c|c|}
\hline & June & Sept. & Nov. & Dec. & Jan. & March \\
\hline $\mathrm{Ca}$ & $9.3(0.5)$ & $9.5(0.4)$ & $9.9(0.5)$ & $9.9(0.4)$ & $9.5(0.6)$ & $9.5(0.6)$ \\
\hline $\mathrm{mg} / 100 \mathrm{ml}$ & $2.3(0.2)$ & $2.5(0.2)$ & $2.5(0.3)$ & $2.4(0.1)$ & $2.5(0.3)$ & $2.5(0.2)$ \\
\hline Inorg. $P$ & $4.7(0.9)$ & $6.1(1.2)$ & $6.2(1.1)$ & $5.9(1.0)$ & $6.4(1.0)$ & $6.2(1.0)$ \\
\hline Alk. phos. m.u./ml & $13.7(6.3)$ & $15.0(11.3)$ & $11.7(5.8)$ & $11.3(4.8)$ & $14.5(8.9)$ & $13.1(7.5)$ \\
\hline
\end{tabular}




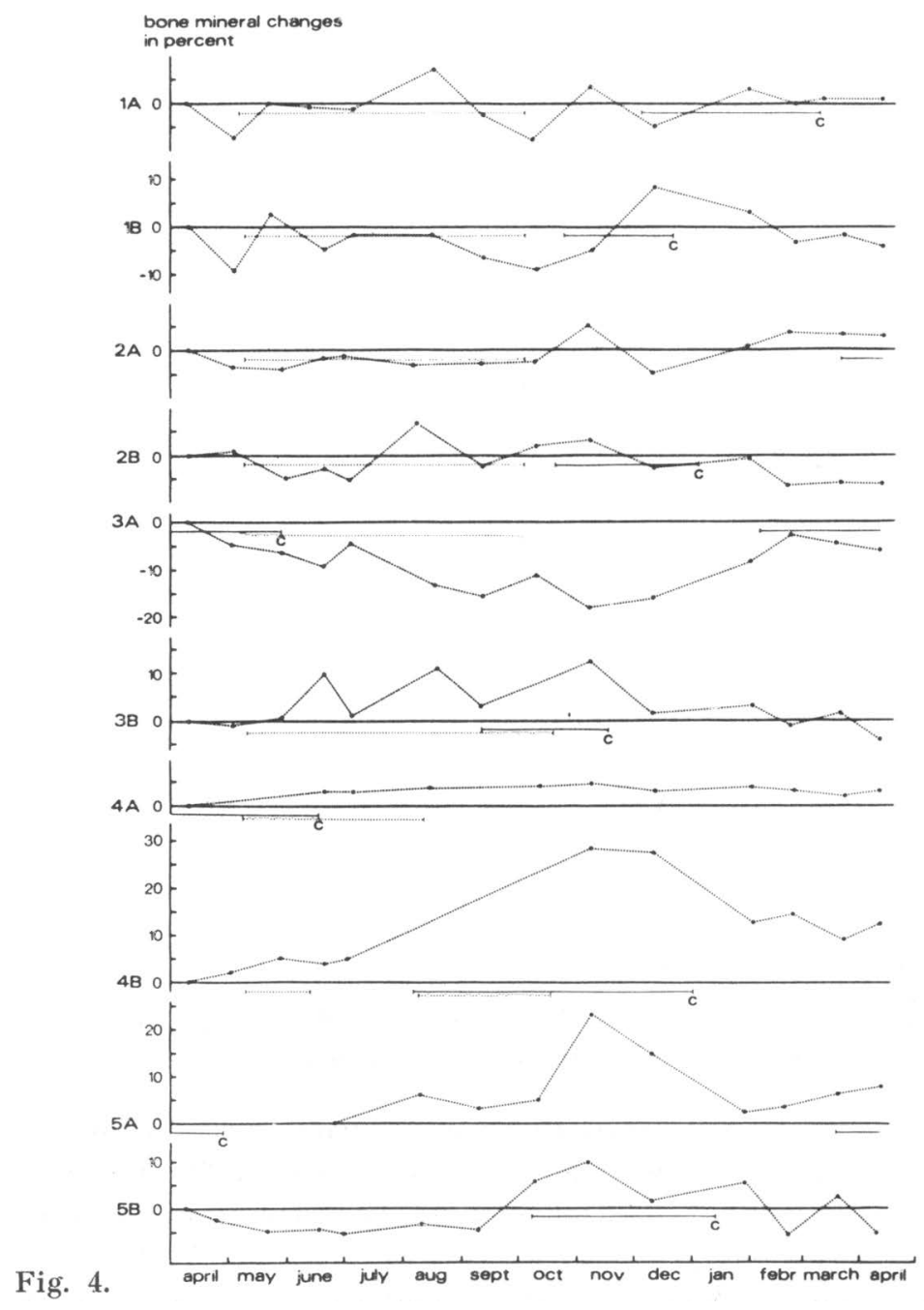

F i g u r e s $4-5$. Changes of individual BMC. Values are expressed as percentage deviation from the first value obtained. $C$ indicates day of calving. The thin black line below the $x$-axis represents dry period and the dotted line period on pasture.

\section{DISCUSSION}

The A set was homogenous in composition as it consisted of healthy growing animals of the same age. The fact that these animals all had similar changes in BMC with good correlation 


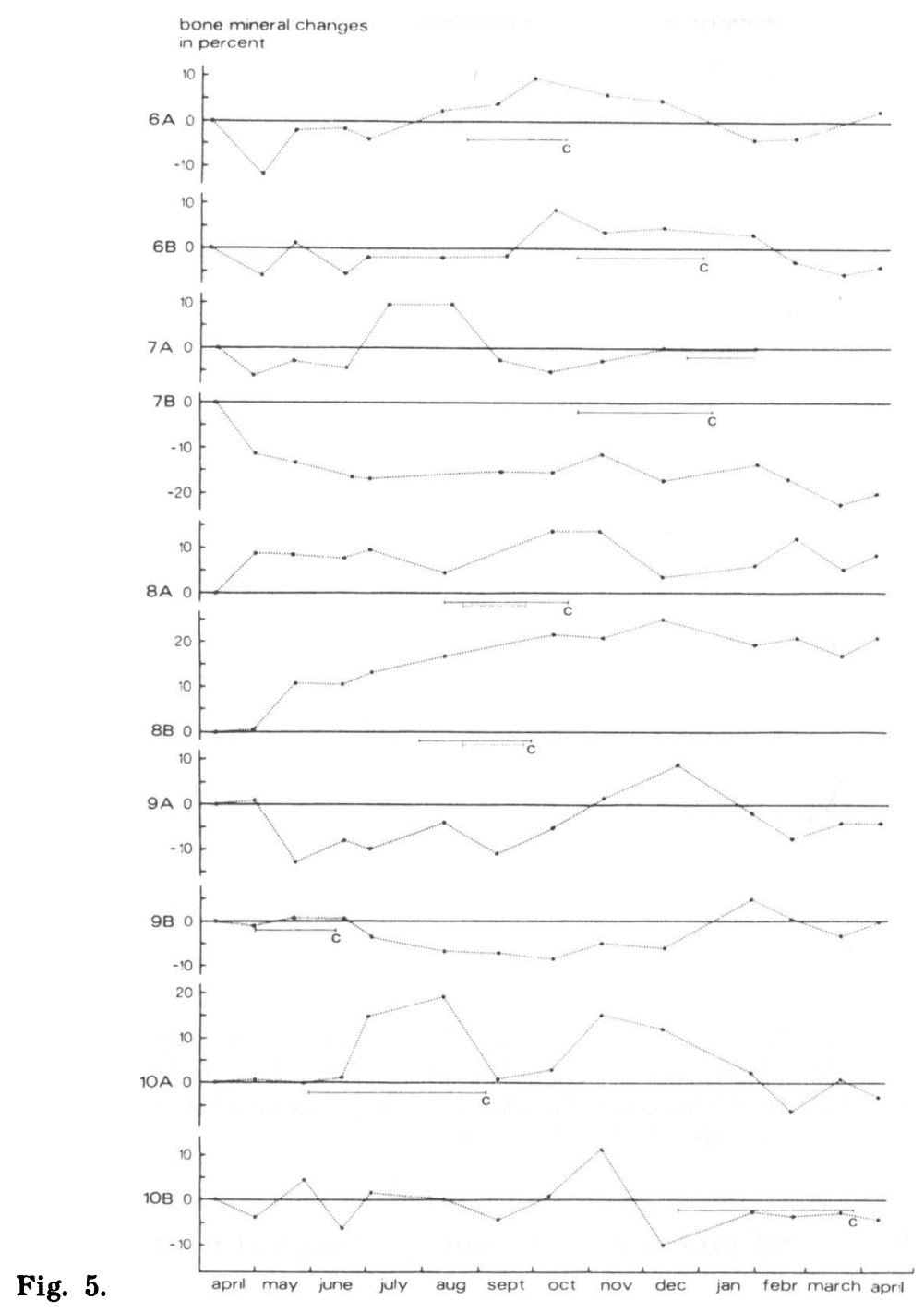

between increase in body weight and BMC makes it possible to draw the following conclusions. Dichromatic photon absorptiometry applied on the coccygeal vertebrae in cattle provides values, the changes of which seem to be representative for the changes of the entire skeletal BMC. Hence, the present technique does not seem to cause local changes in BMC, as could be suspected considering the fact that there were repeated epidural 


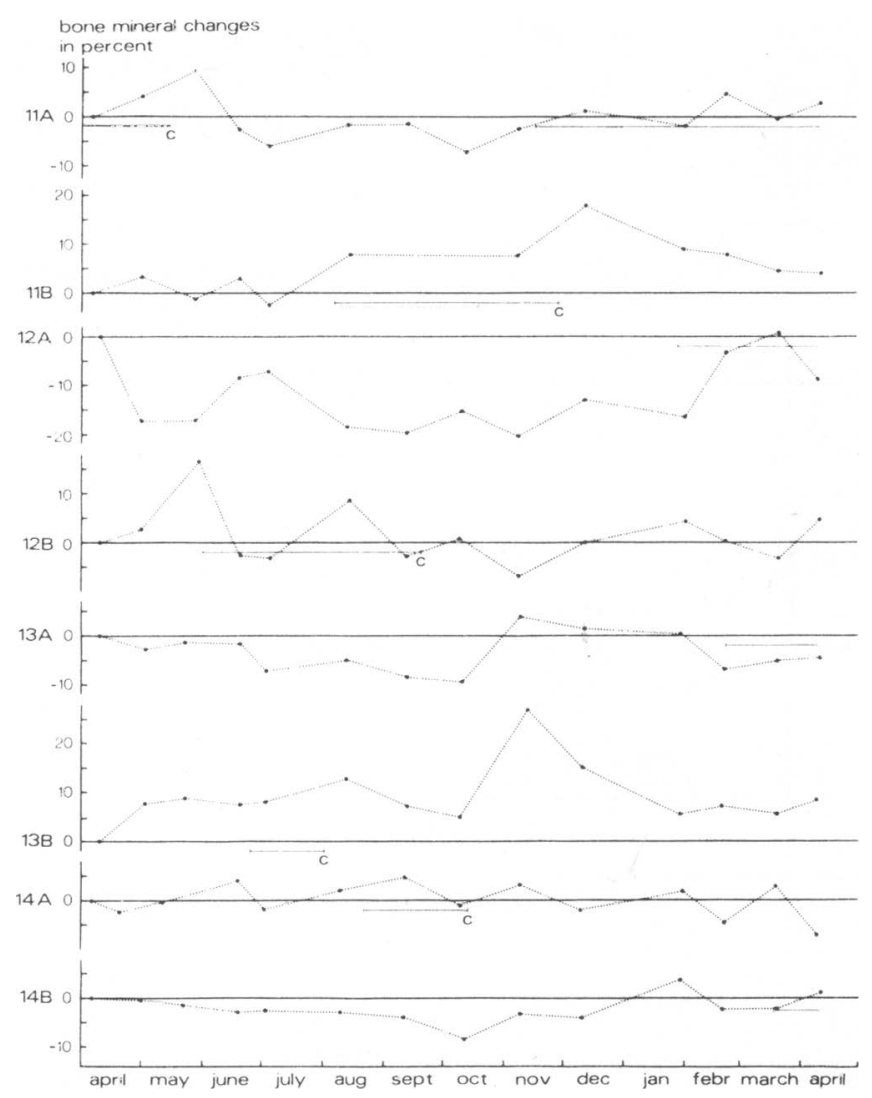

Figure 6. Changes of individual BMC. Values are expressed as percentage deviation from the first value obtained. $C$ indicates day of calving. The thin black line below the $x$-axis represents dry period and the dotted line period on pasture.

anaesthesias and pressure on the tail by clamps at each examination,

The finding that $\mathrm{BMC}$ increased slightly more than the weight is interesting, but at present time it is not clear how this should be interpreted.

The animals in the B set made up a less homogenous group, as age varied and the lactation periods were spread over the year. The fact that there were 14 pairs of identical twins in this set could not be properly taken advantage of. The twins were fed and kept in the same way and thus their environment was the same. It would have been useful to study the influence of 


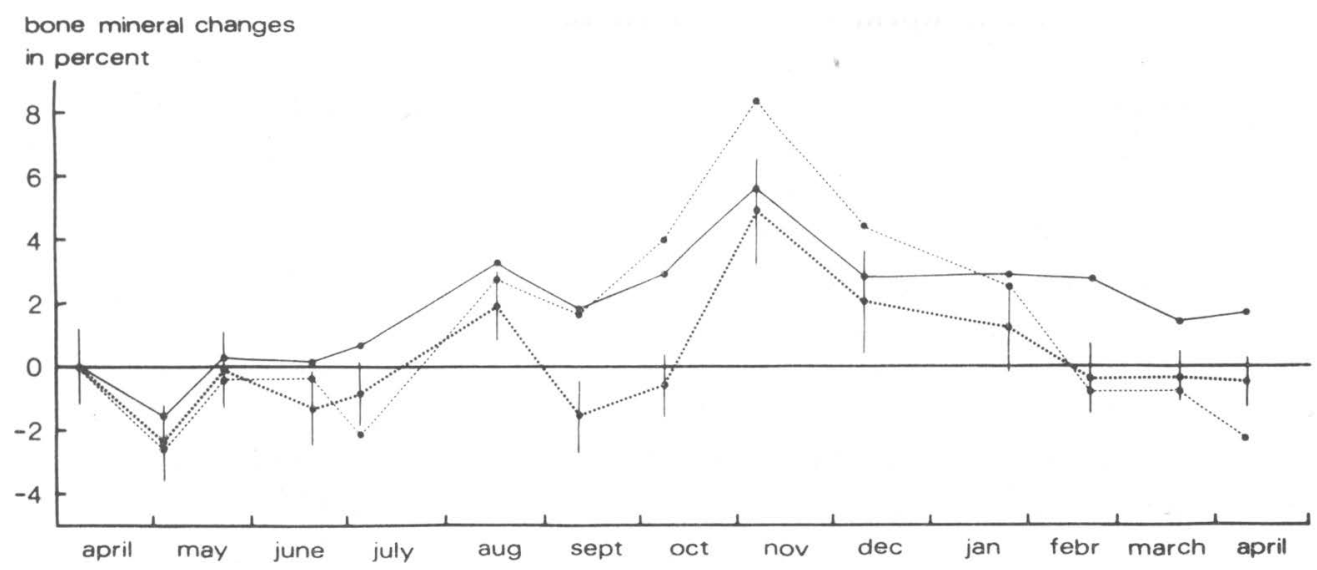

Figure 7. Bone mineral (mean \pm 1 s.e.m.) in the cows of B set (thick dotted line). Bone mineral changes (mean) in cows which calved during the second half of investigation (thin dotted line). Bone mineral changes (mean) in cows on pasture (solid line).

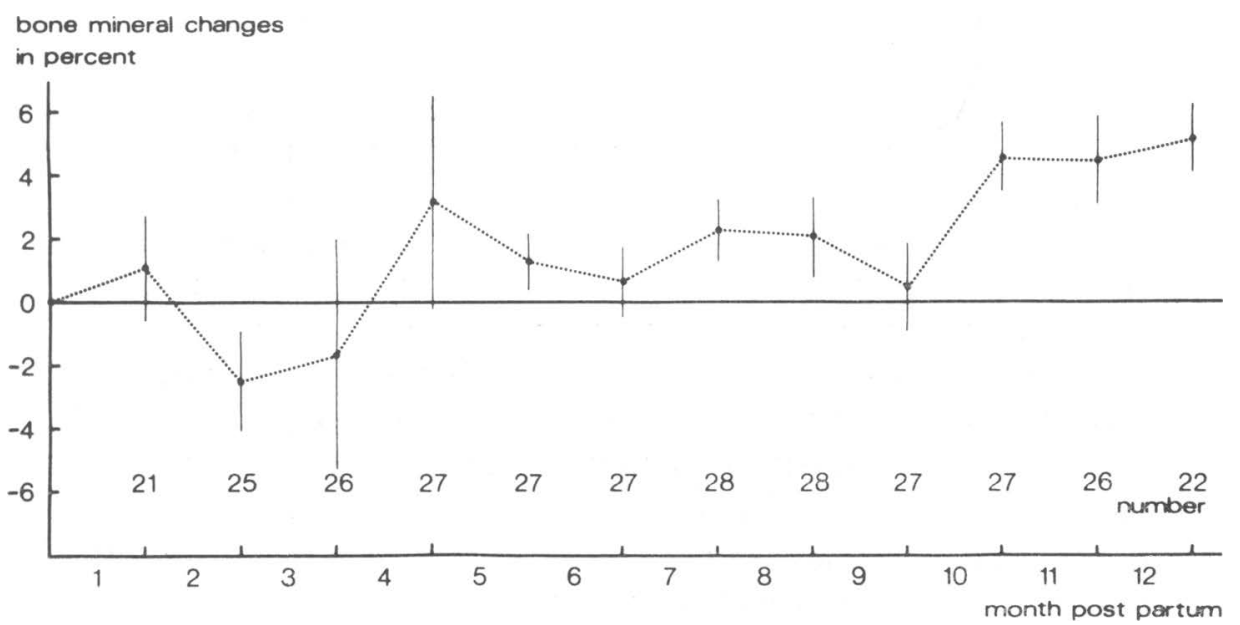

Figur e 8. Bone mineral changes (mean \pm 1 s.e.m.) during year of lactation.

different environments (high or low Ca, pasture or indoor feeding) on BMC in genetically identical individuals.

The great variation in BMC in many of the cows during the period of investigation, and the great difference in BMC changes even in identical twins with relatively coordinated calvings cannot be explained in detail. There are many factors, not studied 
in the present work, which govern resorption and excretion of $\mathrm{Ca}$ as well as accretion and resorption of bone. The results indicate, however, that the bone tissue of the skeleton of adult dairy cows is being turned over at a comparatively high rate. This is a rather unexpected finding. It has previously been shown (Zetterholm 1972) that bone mass increases over the years, mainly in bulls, but also in cows. It has been postulated that this increase in bone mass is the result of decreased bone resorption caused by increased production of calcitonin, in its turn induced by a high Ca intake (Krook et al. 1971). The finding in the present study indicates that the rate of both bone formation and resorption is high. Apparently, formation rate is higher than resorption rate as the skeletal mass increases over the years.

The changes in mean BMC during the year of investigation with no consideration taken to day of calving demonstrate a peak value in late October and early November. There could be several explanations for this. The home-produced fodder probably has the best quality early after harvest, and Ca resorption could therefore be highest at that time. There is, however, a more likely explanation. A study of the distribution of the calvings demonstrates that most of them took place in December and January. Hence, the cows which calved at this time were in the dry period in October-November, and therefore lost only small amounts of $\mathrm{Ca}$. This could be verified by comparing the mean BMC with the value obtained closest to calving. By so doing it was seen that the mean BMC actually is lowered during early lactation and increased during the dry period.

The present investigation indicates that lactation and pregnancy affect BMC. It would therefore be of great interest to find out to what extent low and high calcium feeding can affect BMC during the various periods of lactation and pregnancy.

\section{REFERENCES}

Krook, L., L. Lutwak, K. McEntee, P.-A. Henriksson, K. Braun \& S. Roberts: Nutritional hypercalcitoninism in bulls. Cornell Vet. $1971,61,625-639$.

Zetterholm, R.: Osteopetrosis and hyperostosis in cattle. Proc. 2nd Int. Conf. vet. Radiologists, Stockholm 1970. Acta radiol. (Stockh.) 1972, Suppl. 319, 107-116.

Zetterholm, R. \& N. Dalén: Bone mineral determination in coccygeal vertebrae by dichromatic photon absorptiometry. Acta vet. scand. 1978, 19, $1-17$. 


\section{SAMMANFATTNING \\ Benmineralförändringar hos växande, dräktiga och lakterande nötkreatur.}

Benmineralinnehållet $i$ en eller två svanskotor bestämdes med dikromatisk foton absorptiometri ungefär en gång i månaden hos två grupper av djur.

A. Denna grupp bestod av 6 växande tjurar, och mätningarna pågick i c:a 8 mån. Benmineralinnehållet ökade med tillväxten och denna ökning var signifikant större än viktökningen.

B. I denna grupp ingick 28 kor. Benmineralinnehållet mättes under laktation och dräktighet. Det visade sig att benmineralinnehållet ökade under sinperioden och minskade under höglaktationen. Stor individuell variation förelåg i benmineralinnehållet. Skelettets mineralomsättning var större än väntat.

Resultaten av arbetet pekade på att benmineralförändringarna i svanskotorna väl avspeglar förändringarna i skelettet $i$ sin helhet. Det visade också att laktationen med sitt kalciumdränage och sinperioden då detta dränage upphör hos mjölkkor är de perioder som är av avgörande betydelse för uppkomsten av större förändringar i skelettets kalciuminnehåll. De visade att större förändringar i skelettets kalciuminnehåll endast uppkommer under höglaktationen och under speciella betingelser $\mathrm{i}$ sinperioden.

(Received April 28, 1977).

Reprints may be requested from: The Department of Animal Hygiene, Animal Science Centre, College of Veterinary Medicine, S-750 07 Uppsala 7, Sweden. 